\title{
Exploration of Plant Growth-Promoting Actinomycetes for Biofortification of Mineral Nutrients
}

\author{
A. Sathya, R. Vijayabharathi, and S. Gopalakrishnan
}

\begin{abstract}
Mineral malnutrition, especially Fe and Zn, affects more than two million people around the world and increases vulnerability to illness and infections. These malnourished people live in developing countries and rely upon staple foods routinely with inability to either afford for dietary diversification or pharmaceutical supplementation or industrial fortification of minerals. Biofortification is a strategy that can tackle hidden hunger merely through staple foods that people eat every day. This strategy can be achieved through agronomic practices and conventional breeding and genetic engineering approaches, and each has their own pros and cons. The sustainability of such grain fortification with higher seed mineral concentration is soil health dependent, especially on the availability of mineral in the rhizosphere. Microorganisms, the invisible engineers in improving the soil health by solubilizing trace elements and by driving various biogeochemical cycles of soil, have the ability to serve as a key solution for this complex issue. In specific, plant growthpromoting (PGP) microbes reside in root-soil interface and employ the use of siderophores, organic acids, and exopolysaccharides for increasing the mineral availability and subsequent mobilization to the plants. Increasing the seed mineral density with the use of such PGP microbes, especially actinomycetes, is in its infancy. Hence, this chapter is aimed to bring a view on the role of microbes, especially actinomycetes, with metal-mobilizing and PGP traits for biofortification as this strategy may
\end{abstract}

\footnotetext{
A. Sathya $・$ R. Vijayabharathi $\bullet S$. Gopalakrishnan $(\bowtie)$ International Crops Research Institute for the Semi-Arid Tropics (ICRISAT), 502 324, Patancheru, Hyderabad, Telangana, India e-mail: s.gopalakrishnan@cgiar.org
} 
act as a complementary sustainable tool for the existing biofortification strategies.

\section{Keywords}

Biofortification • Minerals • Iron • Zinc • Grain legumes • Soil fertility • Plant growth-promoting microbes $\bullet$ Actinobacteria

\subsection{Introduction}

Peace and welfare of the human society depends fundamentally on a sufficient, balanced, and secure supply of food. But in the present scenario, undernourishment is one of the serious problems faced by poor people living in developing countries. Recent reports of FAO states that chronic undernourishment is estimated about 805 million people around the world during 2012-2014, of which about 791 million are in developing countries. Though an overall reduction of 203 million undernourished people has occurred from the last two decades, still one in eight people in these regions, or $13.5 \%$ of the overall population, remain chronically underfed (FAO et al. 2014). The resulting food insecurity is closely linked with nutritional insecurity/malnutrition. During the discussion of world hunger, protein energy malnutrition (PEM), also called classical hunger, is highly referred because most of the hungry and undernourished people live on a mono-carbohydrate diet such as maize or rice. Incidences of PEM have been the cause for the death of $35 \%$ of the children below 5 years of age (FAO et al. 2012). Though meat-based diet is an option to overcome PEM, its continuous supply to the developing countries is unrealistic because of high cost, high energy requirement, land and water resources for the maintenance of animal-based food systems, and also religious constraints (Pimentel and Pimentel 2003).

From the past two decades, the definition of malnutrition also covers "hidden hunger," a form of hunger also called micronutrient deficiency, caused by chronic lack of vitamins and minerals (WHO 2004). The consequences of hidden hunger will not be visible immediately, and it continues to affect the entire population though the food supply is adequate in preventing classical hunger (Kennedy et al. 2003). According to the Global Hunger Index 2014, there are two billion people suffering from hidden hunger (von Grebmer et al. 2014). Besides individual health, development, and productivity, it has subsequent socioeconomic consequences affecting overall economic growth and national income (Arcand 2001). Hence, FAO recommended to introduce nutritional-related indicators additionally in one of the dimensions of food security called "utilization" which is denoted from 2013 onward in "The State of Food Insecurity in the World" (FAO et al. 2013). The current indicators of the utilization dimension include:

1. Percentage of children under 5 years of age affected by wasting

2. Percentage of children under 5 years of age who are stunted

3. Percentage of children under 5 years of age who are underweight

4. Percentage of adults who are underweight

5. Prevalence of anemia among pregnant women

6. Prevalence of anemia among children under 5 years of age

7. Prevalence of vitamin A deficiency in the population

8. Prevalence of iodine deficiency in the population (FAO et al. 2014)

Among the micronutrient deficiencies, mineral malnutrition has higher prevalence than vitamin deficiency as it holds various facets such as (1) high impact for iron (Fe), zinc ( $\mathrm{Zn})$, and iodine (I) (WHO 2002), (2) less impact for calcium (Ca) and selenium (Se) (WHO 2004), and impact at subpopulations or at regional levels for 
magnesium $(\mathrm{Mg})$ and copper $(\mathrm{Cu})$ (White and Broadley 2009). Among them, Fe deficiency $(\mathrm{FeD})$ and $\mathrm{Zn}$ deficiency $(\mathrm{ZnD})$ are the prevalent mineral deficiencies and ranked 9th and 11th, respectively, among the 20 leading health risks. FeD leads to anemia, impaired physical activity, impaired mental development, and maternal mortality with stillbirths and child deaths, while $\mathrm{ZnD}$ has been documented mainly on infants and children with growth disorders, delayed sexual development, increased susceptibility to infection, and immune suppression (Stein 2009). So, a food that supplements for both PEM and hidden hunger is highly important for the current situation.

With this ground information, this book chapter will bring the role of agriculture in the history of hidden hunger especially mineral malnutrition, currently available interventions and their pros and cons, and how a microbe-mediated process, especially actinomycetes, can help in overcoming the root causes of hidden hunger.

\subsection{Agriculture: A Hidden Cause for Hidden Hunger}

The first green revolution begun during the 1960s is the science-based transformation of Third World agriculture which increased the cereal production more than twice and offered solution to the threats of mass starvation in the 1960s and of continuing food shortages during the 1960s and 1970s. This includes the development and use of high-yielding varieties of cereal grains, expansion of irrigation infrastructure, and distribution of hybridized seeds, synthetic fertilizers especially NPK, and pesticides. The continuous use of high-yielding cultivars that have higher response to fertilizers made the soils deficient in their native nutrients especially micronutrients because NPK fertilizers do not supply any of the necessary micronutrients like organic manures. This revolution is also responsible for biodiversity loss due to the loss of many wild and locally adapted cultivars. On the other end, there was a decrease in pulse production and other secondary staples as the developed technology is mostly targeted on cereals resulting in relative price increases for non-cereal crop products (Welch 2002a, b; Graham et al. 2007). For instance, in the Philippines, intensive rice monoculture systems led to the loss of wild leafy vegetables and fish that the resource-poor people had previously harvested from rice paddies (Pingali and Roger 2012). In case of India, the increased pulse prices have been associated with a consequent decline in its consumption across all income groups. This supply-mediated price effects limited the access and hence insufficient minimum daily requirements of micronutrients (Kataki 2002). However, these hidden causes were not prioritized by agricultural researchers and also nutritionists during the revolutionary period.

Though the history of iron deficiency has started before the 1930s (Haden 1938), a steady increase in the extent of iron deficiency anemia in humans was noticed during the 1980s, especially among the resource-poor populations who benefited from the greater cereal productivity of the green revolution (Graham 2008). In case of $\mathrm{ZnD}$, it was initially reported during the 1960 s by Prasad et al. (1963) and later in the 1980s (Prasad 1991). Efforts of this research group were largely ignored, and the impact of $\mathrm{ZnD}$ was recognized only during the 1990s by their further findings (Prasad 2003). This might be due to the lack of quick and simple diagnostics for $\mathrm{ZnD}$ in humans than anemia, and it continued to be largely ignored. During this decade, other micronutrient deficiencies affecting large population such as iodine, selenium, and vitamin A were also given importance (Ren et al. 2008).

It is understood from the previous section that, logically, agricultural farming systems are part of the root causes of hidden hunger, as success of the modern agriculture by the continuous use of high-yielding cultivars made the soils deficient in their native nutrients. This is proved by the study of Garvin et al. (2006) by analyzing micronutrient density of 14 different hard red winter wheat (HRWW) genotypes representing different production eras ranging from 1873 (the year of introduction of HRWW) through the modern breeding era starting in the early 1940s until 2000, in Hutchinson and Manhattan, Kansas, 
USA. A significant negative regression for seed of $\mathrm{Fe}, \mathrm{Zn}$, and Se content on both yield and variety release date was observed. Further evaluation by Fan et al. (2008) confirmed the similar trend in which analysis of mineral concentration from the archived wheat grain and also soil samples over 160 years from Broadbalk wheat experiment was done. This experimental station was established at Rothamsted, England, in 1843 to test the effect of different combinations of inorganic fertilizers and organic manures on wheat yield. The determined micronutrient concentration and the observed trends over time in the context of cultivar, yield, and harvest index revealed that the concentrations of $\mathrm{Fe}, \mathrm{Zn}, \mathrm{Cu}$, and $\mathrm{Mg}$ have remained stable during 1845 to the mid-1960s; later, reductions were observed which coincides with the introduction of semidwarf, high-yielding cultivars. Multiple regression analysis data registered that increasing yield and harvest index were the significant contributors for the downward trend of grain mineral concentration.

These experiments clearly indicate the low mineral availability of soils and observed mainly in developing countries such as Pakistan, China, India, Iran, and Turkey (Cakmak et al. 1999; Alloway 2009). It has been shown that the Indian soils are deficient by $11.2 \%$ in extractable Fe and by $48.1 \%$ in extractable $\mathrm{Zn}$ with an expectation of this deficiency to increase up to $63 \%$. This is due to the difference in total vs. available soil minerals and observed as 4000-273,000 mg/ $\mathrm{kg}$ vs. $0.36-174 \mathrm{mg} / \mathrm{kg}$ for $\mathrm{Fe}$ and $7-2960 \mathrm{mg} / \mathrm{kg}$ vs. $0.1-24.6 \mathrm{mg} / \mathrm{kg}$ for Zn (Gupta 2005; Singh 2009). This was further emphasized by studies in Turkey, where $\mathrm{Zn}$ concentration of wheat grains grown on Zn-sufficient soils ranged between 20 and $30 \mathrm{mg} / \mathrm{kg}$, whereas on the $\mathrm{Zn}$-deficient soils, this range decreased to $5-12 \mathrm{mg} / \mathrm{kg}$ (Kalayci et al. 1999; Erdal et al. 2002).

\subsection{Interventions for Hidden Hunger}

The interventions for hidden hunger include many facets, and a detailed view on this was given by Stein (2009) which was here depicted as an overview in Fig. 17.1. The interventions such as dietary diversification or pharmaceutical supplementation or industrial fortification of minerals could not be affordable by millions of poor people residing in developing countries. In addition, such supplementation is coming up with some restrictions in food intake pattern and requirement of additional supplements for active therapy. For instance, iron supplements should not be taken during the medication with antacids or calcium supplements and food such as high-fiber foods, drinks with caffeine, cheese and yogurt, eggs, milk, and spinach, but it has to be taken with either vitamin $\mathrm{C}$ supplement or citrus juice to enhance iron absorption into the body. On the other hand, the strategy called biofortification can tackle hidden hunger as it merely targets staple foods that people eat every day. Biofortification is a process by which crops are bred in a way that increases their nutritional value especially minerals and vitamins. The currently available strategies for biofortification are agronomic biofortification, conventional plant breeding, and genetic engineering. The agronomic approach employs the application of mineral fertilizers and/or the improvement of the solubilization and mobilization of mineral elements in the soil (White and Broadley 2009; Graham et al. 2012).

The other two biofortification strategies have the highest impact than agronomic fortification, and crops such as iron beans, iron pearl millet, zinc rice, and zinc wheat have been developed and released across many parts of the world through HarvestPlus, a Global Challenge Program of the Consultative Group on International Agricultural Research (CGIAR) (HarvestPlus 2013). Though genetic biofortification has the highest impact than agronomic fortification, it carries some potential risks such as exposure to cancer and non-specificity of $\mathrm{Fe} / \mathrm{Zn}$ genes, if the biofortification strategies were aimed at decreasing anti-nutrients and increasing $\mathrm{Fe} / \mathrm{Zn}$ concentration, respectively (Shahzad et al. 2014). Strengths, weaknesses, opportunities, and threats (SWOT) analysis on these strategies has identified that mineral availability in the soil is the common weakness for conventional breeding 


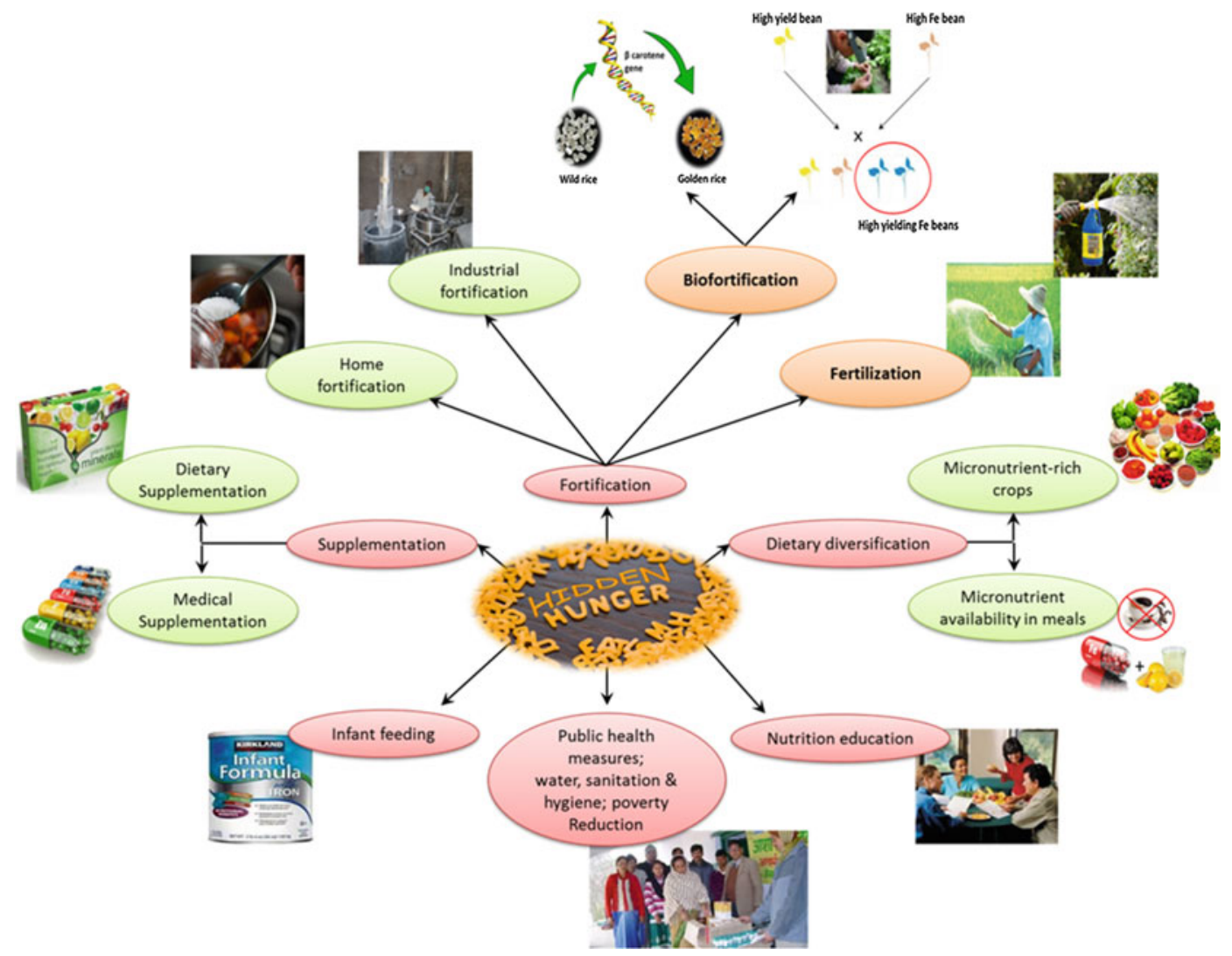

Fig. 17.1 Available interventions for hidden hunger. Interventions of hidden hunger indicated in pink and green shapes are the major and substrategies, respectively. Orange shapes are the strategies targeted through agriculture

and genetic engineering approaches (Carvalho and Vasconcelos 2013). Previous reports have also stated that the key barrier to micronutrient absorption in plants occurs in the root-soil interface (Welch 2001). Hence, it is apparent that enhancing the availability of mineral nutrients is a key process for any kind of biofortification targeting staple crops.

\subsection{Microbes: Hidden Players of Soil Fertility}

Microbes are the largest population that exists in soil with a high diversity index, and its population (number/g soil) includes bacteria $\left(10^{8}-10^{9}\right)$, actinomycetes $\left(10^{7}-10^{8}\right)$, fungi $\left(10^{5}-10^{6}\right)$, algae $\left(10^{4}-10^{5}\right)$, and protozoa $\left(10^{3}-10^{4}\right)$ (Hoorman and Islam 2010). Besides the small voluminous nature, they are the key drivers of biogeochemical cycles involving macroelements $(\mathrm{C}, \mathrm{N}, \mathrm{S}$, and $\mathrm{P})$ and microelements (Fe, $\mathrm{Zn}, \mathrm{Mg}, \mathrm{Cu}, \mathrm{Se}$, and B) (Bloem et al. 1997). In the case of mineral elements, microorganisms enhance the solubility of trace elements through a variety of mechanisms and engineer the plant rhizosphere and improve the soil health.

\subsubsection{Plant Growth-Promoting Microorganisms}

Population density of microbes is generally high in rhizospheric soil (10-100-fold) than bulk soil due to the influence of plant roots as they secrete numerous nutrients such as sugars, 
organic acids, vitamins, amino acids, fatty acids, nucleotides, phenols, and sterols (Uren 2007). These microbial groups may reside at various proximity of roots, viz., near the roots (rhizosphere), root surface (rhizoplane), and inside the root tissue either as free living (endophytes) or as symbionts in specialized root structures or nodules. Many microorganisms living in any of these proximities have the capacity to promote plant growth either directly by influencing nitrogen fixation, $\mathrm{P}$ solubilization, Fe chelation, and phytohormone synthesis or indirectly by suppressing phytopathogens and inducing host plant resistance against biotic and abiotic stresses. These are referred as plant growthpromoting microorganisms and broadly used with the terminology plant growth-promoting rhizobacteria (PGPR) (Glick 1995; Bhattacharyya and Jha 2012). PGPR are reported from a wide range of plants such as cereals (de Souza et al. 2013; Majeed et al. 2015), pulses (Medeot et al. 2010; Wahyudi et al. 2011), vegetables (Abhishek et al. 2013; Agrawal and Agrawal 2013), fruits (Mehta et al. 2013; Thokchom et al. 2014), medicinal plants (Ahmed et al. 2014; Egamberdieva et al. 2015) and tree species (Donate-Correa et al. 2005; Barriuso et al. 2008; Singh et al. 2011) and also environmental conditions of temperate (Trivedi and Pandey 2008), arid (Silini-Chérif et al. 2012), and semiarid regions (Kavamura et al. 2013) and also high altitudes (Zahid et al. 2015). They were also documented in polluted soils containing petroleum, sewage sludge, dye, and heavy metals (Belimov et al. 2001; Liu et al. 2014). This indicates the omnipresence of PGPR on various natural and contaminated soils and climatic conditions.

\subsection{Metal-Mobilizing PGPR in Biofortification}

Among the microbes, PGPR reside in metalliferous soil with higher metal solubilizing and extracting capacity which can play decisive role in the context of soil mineral density and biofortification. Many of such isolates reported for one or multiple plant growth-promoting (PGP) traits such as production of indole acetic acid (IAA), siderophore, and 1- aminocyclopropane-1-carboxylate (ACC) deaminase; solubilization of $\mathrm{Zn}, \mathrm{P}$, and $\mathrm{K}$; and $\mathrm{N}_{2}$ fixation. Some of the examples are Enterobacter, Pseudomonas, Bacillus, Rhizobium, Bradyrhizobium, and Streptomyces. From the literature data, it is understood that PGP actinomycetes were not explored much in this area than other microbial groups, though they are higher stress-tolerant microbes and are found to produce higher ACC deaminase, a stress-relieving enzyme (Ma et al. 2011; Rajkumar et al. 2012; Nascimento et al. 2014), and demonstrated for plant growth-promoting potentials in many cereals, legumes, and vegetable crops (Gopalakrishnan et al. 2013, 2014; El-Tarabily and Sivasithamparam 2006; ElTarabily 2008). Some of the representative reports stating the potential of PGP actinomycetes with metal mobilization traits were given in Table 17.1.

Microbes with metal-mobilizing and PGP traits were evaluated mostly on nonedible/ hyper-accumulating plants and on toxic metals in the area of phytoremediation. Such works on edible crops were a few. A metal-resistant PGP bacterium, Bacillus weihenstephanensis SM3, has been found to promote higher growth rate and $\mathrm{Zn}, \mathrm{Cu}$, and $\mathrm{Ni}$ uptake in Helianthus annuus upon its inoculation (Rajkumar et al. 2008). Similar effects were also identified by Pseudomonas sp., on Ricinus communis at contaminated sites (Rajkumar and Freitas 2008). A metal-tolerant PGP fungus Trichoderma virens PDR-28 has been found to enhance the growth rate of maize and also the absorption of $\mathrm{Cd}, \mathrm{As}, \mathrm{Zn}, \mathrm{Cu}$, and $\mathrm{Pb}$ (Giridhar Babu et al. 2014). On pea, a metaltolerant PGP Rhizobium sp. was shown to produce better growth performance and $\mathrm{Zn}$ uptake in a metal-amended soil (Wani et al. 2008). Similarly, PGP Enterobacter sp. has been observed to increase the growth and metal $(\mathrm{Zn}, \mathrm{Cr}$, and $\mathrm{Ni})$ accumulation in Brassica juncea (Kumar et al. 2008).

Metal-mobilizing property of microbes is aided by its substances such as siderophores, organic acids, biosurfactants, polymeric 
Table 17.1 Metal mobilization potential of PGP actinomycetes

\begin{tabular}{|c|c|c|c|c|c|}
\hline Actinomycetes & Source & $\begin{array}{l}\text { Identified } \\
\text { PGP/metal } \\
\text { mobilization traits }\end{array}$ & $\begin{array}{l}\text { Plant } \\
\text { studied }\end{array}$ & $\begin{array}{l}\text { Exhibited } \\
\text { effects }\end{array}$ & References \\
\hline \multicolumn{6}{|l|}{ Nonedible crops } \\
\hline $\begin{array}{l}\text { Microbacterium } \\
\text { oxydans AY509223 }\end{array}$ & $\begin{array}{l}\text { Rhizosphere of } \\
\text { Alyssum murale } \\
\text { grown in Ni-rich } \\
\text { serpentine soil }\end{array}$ & Ni mobilization & A. murale & $\begin{array}{l}\text { Increased } \mathrm{Ni} \\
\text { uptake in the } \\
\text { low }(36 \%) \text {, } \\
\text { medium } \\
(39 \%) \text {, and } \\
\text { high }(27 \%) \mathrm{Ni} \\
\text { soils }\end{array}$ & $\begin{array}{l}\text { Abou- } \\
\text { Shanab } \\
\text { et al. (2008) }\end{array}$ \\
\hline $\begin{array}{l}\text { Streptomyces sp., } \\
\text { Agromyces sp. }\end{array}$ & $\begin{array}{l}\text { Rhizosphere of } \\
\text { willows growing on } \\
\text { a contaminated site } \\
\text { in Arnoldstein, } \\
\text { Austria }\end{array}$ & $\begin{array}{l}\text { Siderophore, IAA, } \\
\text { Zn, and Cd } \\
\text { immobilization } \\
\text { (except for } \\
\text { Agromyces sp.) }\end{array}$ & $\begin{array}{l}\text { Salix } \\
\text { caprea }\end{array}$ & $\begin{array}{l}\text { Increased plant } \\
\text { leaf biomass, } \\
\text { decreased Cd } \\
\text { and } \mathrm{Zn} \text { uptake } \\
\text { (except for } \\
\text { Agromyces) }\end{array}$ & $\begin{array}{l}\text { Kuffner } \\
\text { et al. (2008) }\end{array}$ \\
\hline \multicolumn{6}{|l|}{ Edible crops } \\
\hline $\begin{array}{l}\text { Azotobacter } \\
\text { chroococcum } \mathrm{HKN}-5\end{array}$ & $\begin{array}{l}\text { Agronomic soils in } \\
\text { Hong Kong }\end{array}$ & $\begin{array}{l}\mathrm{N} \text { fixation, } \mathrm{P} \text { and } \mathrm{K} \\
\text { solubilization, } \\
\text { metal mobilization }\end{array}$ & $\begin{array}{l}\text { Brassica } \\
\text { juncea }\end{array}$ & $\begin{array}{l}\text { Increased plant } \\
\text { aboveground } \\
\text { biomass }\end{array}$ & $\begin{array}{l}\mathrm{Wu} \\
\text { et al. (2009) }\end{array}$ \\
\hline Rhodococcus sp. Fp2 & \multirow{2}{*}{$\begin{array}{l}\text { Cr-contaminated } \\
\text { site situated in the } \\
\text { Indian Himalayan } \\
\text { Region }\end{array}$} & \multirow{2}{*}{$\begin{array}{l}\text { Metal } \\
\text { detoxification } \\
\text { mechanism }\end{array}$} & \multirow{2}{*}{$\begin{array}{l}\text { Pisum } \\
\text { sativum }\end{array}$} & \multirow{2}{*}{$\begin{array}{l}\text { Increased plant } \\
\text { growth }\end{array}$} & \multirow{2}{*}{$\begin{array}{l}\text { Trivedi } \\
\text { et al. (2007) }\end{array}$} \\
\hline $\begin{array}{l}\text { Rhodococcus } \\
\text { erythropolis } \mathrm{MtCC} \\
7905\end{array}$ & & & & & \\
\hline $\begin{array}{l}\text { Streptomyces } \\
\text { acidiscabies } \mathrm{E} 13\end{array}$ & $\begin{array}{l}\text { Former uranium } \\
\text { mine, Wismut, in } \\
\text { eastern Thuringia, } \\
\text { Germany }\end{array}$ & $\begin{array}{l}\text { IAA and } \\
\text { siderophore: } \\
\text { desferrioxamine E, } \\
\text { desferrioxamine B, } \\
\text { and coelichelin }\end{array}$ & $\begin{array}{l}\text { Vigna } \\
\text { unguiculata }\end{array}$ & $\begin{array}{l}\text { Increased } \\
\text { height and } \\
\text { biomass }\end{array}$ & $\begin{array}{l}\text { Dimkpa } \\
\text { et al. (2008) }\end{array}$ \\
\hline $\begin{array}{l}\text { Streptomyces tendae } \\
\text { F4 }\end{array}$ & $\begin{array}{l}\text { Former uranium } \\
\text { mine, Wismut in } \\
\text { eastern Thuringia, } \\
\text { Germany }\end{array}$ & $\begin{array}{l}\text { Siderophore: } \\
\text { desferrioxamine B, } \\
\text { desferrioxamine E, } \\
\text { and coelichelin }\end{array}$ & $\begin{array}{l}\text { Helianthus } \\
\text { annuus }\end{array}$ & $\begin{array}{l}\text { Enhanced Cd } \\
\text { and Fe uptake } \\
\text { by plants } \\
\text { through } \\
\text { facilitating their } \\
\text { mobilization }\end{array}$ & $\begin{array}{l}\text { Dimkpa } \\
\text { et al. (2009) }\end{array}$ \\
\hline Azotobacter spp. & $\begin{array}{l}\text { Manganese mine } \\
\text { spoil dump near } \\
\text { Gurgaon, India }\end{array}$ & $\begin{array}{l}\text { Extracellular } \\
\text { polymeric } \\
\text { substances or cell } \\
\text { wall } \\
\text { lipopolysaccharides }\end{array}$ & $\begin{array}{l}\text { Triticum } \\
\text { aestivum }\end{array}$ & $\begin{array}{l}\text { Immobilized } \mathrm{Cd} \\
\text { and } \mathrm{Cr} \text { and } \\
\text { decreased their } \\
\text { uptake }\end{array}$ & $\begin{array}{l}\text { Joshi and } \\
\text { Juwarkar } \\
(2009)\end{array}$ \\
\hline $\begin{array}{l}\text { Arthrobacter } \\
\text { sp. MT16, Azotobacter } \\
\text { vinelandii GZC24, } \\
\text { Microbacterium } \\
\text { sp. JYC17, and } \\
\text { Microbacterium } \\
\text { lactium YJ7 }\end{array}$ & $\begin{array}{l}\mathrm{Cu} \text {-tolerant plant } \\
\text { species growing on } \\
\text { a Cu mine } \\
\text { wasteland, Nanjing, } \\
\text { China }\end{array}$ & $\begin{array}{l}\text { ACC deaminase, } \\
\text { siderophore, IAA, P } \\
\text { solubilization }\end{array}$ & $\begin{array}{l}\text { Brassica } \\
\text { napus }\end{array}$ & $\begin{array}{l}\text { Increased root } \\
\text { length } \\
\text { promotion }\end{array}$ & $\begin{array}{l}\mathrm{He} \\
\text { et al. (2010) }\end{array}$ \\
\hline $\begin{array}{l}\text { Streptomyces mirabilis } \\
\mathrm{P} 16 \mathrm{~B}-1\end{array}$ & $\begin{array}{l}\text { Heavy metal- } \\
\text { contaminated soil } \\
\text { derived from a } \\
\text { former uranium } \\
\text { mining site in } \\
\text { Ronneburg, } \\
\text { Germany }\end{array}$ & $\begin{array}{l}\text { Siderophore: } \\
\text { ferrioxamines E, } \\
\mathrm{B}, \mathrm{D} \text {, and } \mathrm{G}\end{array}$ & $\begin{array}{l}\text { Sorghum } \\
\text { bicolor }\end{array}$ & $\begin{array}{l}\text { Increased plant } \\
\text { biomass }\end{array}$ & $\begin{array}{l}\text { Schütze } \\
\text { et al. (2014) }\end{array}$ \\
\hline
\end{tabular}


substances, and glycoprotein and the reaction such as metal reduction and oxidization and biosorption. The mechanism behind the metal mobilization process through these substances was reviewed in detail (Ma et al. 2011; Rajkumar et al. 2012; Sessitsch et al. 2013).

\subsubsection{PGPR in Biofortification of Cereal and Leguminous Crops}

The research frontiers mentioned on biofortification through PGPR are studied to certain extent at international and national level but not extensively. Initial studies of Rana et al. (2012a) on wheat under glasshouse conditions documented that combination of rhizobacterial strains Bacillus sp. AW1 and Providencia sp. AW5 enhanced 14-34\% of plant biometric parameters along with the increase of $28-60 \%$ in mineral content with the higher counts for Fe. Further studies on wheat field trials revealed that PGP Providencia sp., having P, Zn, and Fe solubilization capacity, increased the Fe content by $105 \%$ (Rana et al. 2012b). Recently, they investigated the effect of PGPR (Brevundimonas diminuta PR7, Ochrobactrum anthropi PR10, and Providencia sp. PW5) and cyanobacteria (Anabaena oscillarioides CR3), alone and in combination on mineral enrichment and yield in rice-wheat sequence, for a period of 2 years. In rice, combination of Providencia sp., $B$. diminuta, and $O$. anthropi recorded higher enhancement of about $13-16 \%$ of $\mathrm{Fe}, \mathrm{Zn}, \mathrm{Cu}$, and $\mathrm{Mn}$. In the case of wheat, Providencia sp. alone registered higher enrichment of $\mathrm{Fe}$ and Cu by $45 \%$ (Rana et al. 2015). Co-inoculation of some cyanobacteria Anabaena with Azotobacter or Providencia on 11 maize hybrids showed a positive correlation with $\mathrm{Zn}$ concentration in the flag leaf (Prasanna et al. 2015). A PGP strain Pseudomonas aeruginosa isolated from roots of Vigna mungo has PGP traits and Zn solubilization potential. Under pot trials on wheat, it increased soil enzyme activities and grain $\mathrm{Zn}$ content by about $85 \%$ in comparison to the control plants grown in Zn-deficient soil (Sirohi et al. 2015). Similarly, PGP Pseudomonas putida
B17 and B19 exhibited the translocation efficiency of the Fe from roots to grains and led to the increased grain $\mathrm{Fe}$ content by twofolds (Sharma et al. 2013).

As like cereals, in leguminous crops also few studies were carried for biofortification by PGPR, but they have an additional advantage over cereals, because their characteristic pattern of high protein and minerals helps in overcoming both classical and hidden hunger. In the realm of biofortification, a recent study had revealed that arbuscular mycorrhizal (AM) fungal colonization on chickpea roots had enhanced the crop growth, productivity, plant nutrient uptake, and grain fortifications with enhanced protein, $\mathrm{Fe}$, and $\mathrm{Zn}$ under a rainfed low-input cropping system (Pellegrino and Bedini 2014). A collection of AM fungal inoculum (Acaulospora spp., Acaulospora cavernata, Acaulospora spinosa, Claroideoglomus etunicatum, Diversispora spurca, Funneliformis coronatum, Funneliformis geosporum, Funneliformis mosseae, Glomus spp., Rhizophagus clarus, Rhizophagus irregularis, Scutellospora aurigloba, Scutellospora calospora, and Septoglomus viscosum) had shown $8 \%$ and $36 \%$ increase in Fe and Zn, respectively. Verma et al. (2013) had documented the effect of two PGPR isolates, Mesorhizobium sp., and Pseudomonas sp., on chickpea yield under greenhouse and field conditions of Varanasi, Uttar Pradesh. The efficiency of Mesorhizobium sp., in enhancing $\mathrm{N}_{2}$ fixation and Pseudomonas sp., in enhancing $\mathrm{P}$ and $\mathrm{Fe}$ acquisition has also been registered. Similar results were reported by Rudresh et al. (2005) using a consortium of Rhizobium sp., phosphate solubilizing Bacillus megaterium subsp. phospaticum and Trichoderma sp. on chickpea under greenhouse and field conditions of Bangalore, Karnataka. Recent study of Khalid et al. (2015) on chickpea further supports the ability of PGP bacterial strains with siderophore-producing capacity in increasing $\mathrm{Fe}$ concentration by 81 and $75 \%$ in grain and shoot over the control treatments under greenhouse conditions. Some of the PGP Streptomyces from our microbial collection showed increase in the grain $\mathrm{Fe}$ and $\mathrm{Zn}$ content by $18 \%$ and $9 \%$, 
respectively, in chickpea (unpublished results). Though the actinomycetes were not reported in the context of biofortification, previously demonstrated effects on their metal mobilization property along with PGP reveal that actinomycetes are able to mobilize/solubilize minerals and metals in a wide range of food crops including cereals, oil seed, and leguminous crops (Table 17.1). It is also noted that actinomycetes employ multiple PGP traits necessary for mineral mobilization such as production of various siderophores and extracellular polymeric substances along with IAA and ACC deaminase. Still, potential actinomycete isolates have to be explored for enhanced mineral solubilization/mobilization rates under field conditions. So it is postulated that use of such potential PGP actinomycetes can improve mineral density of grains in not only staple crops but also in other secondary staple crops. This further protects the soil fertility and biodiversity loss, the major threats raised during the adaptation of hybridized crops, and hence offers sustainable solution for biofortification.

\subsection{Conclusions}

The information available for microbes in enhancing soil macro- and micronutrients is voluminous. However, the focus of biofortification of grain minerals through PGP microbes, particularly on actinomycetes, is in its infancy, and only a limited number of reports are available. On the other hand, many microbial groups from PGP microbes have been evaluated for the metal-mobilizing property in the context of microbe-mediated phytoremediation in nonfood crops, since they can act quickly and enhance the remediation rates. Though phytoremediation and biofortification can be considered as two sides of one coin and employ the central core of metal mobilization and accumulation to the harvestable or edible parts of plants, metal-mobilizing microbes especially PGP actinomycetes are not evaluated for the latter. Only the microbes from rhizospheric soil were evaluated on wheat and maize in case of cereals and on pea and chickpea in case of legumes. Though appreciable quantities of $\mathrm{Fe}$ and $\mathrm{Zn}$ have been observed in grains through the use of PGP microbes, most of the studies are done under glasshouse conditions. Further characterization of PGP microbes, especially of actinomycetes, from rhizospheric and metalliferous soil under various field conditions helps in understanding the role of metalmobilizing PGP bacteria in accumulating grain minerals. The success of this strategy can bring a complementary sustainable tool for the existing biofortification strategies and substantially reduce the chemical fertilizer inputs and reduce protein and mineral malnutrition incidences in developing countries.

\section{References}

Abhishek W, Preeti M, Anjali C, Shirkot CK (2013) Antagonistic activity of plant growth-promoting rhizobacteria isolated from tomato rhizosphere against soil borne fungal plant pathogens. Int J Agric Environ Biotechnol 6:571-580

Abou-Shanab RA, Ghanem K, Ghanem N, Al-Kolaibe A (2008) The role of bacteria on heavy-metal extraction and uptake by plants growing on multi-metalcontaminated soils. World J Microbiol Biotechnol 24:253-262

Agrawal DPK, Agrawal S (2013) Characterization of Bacillus sp. strains isolated from rhizosphere of tomato plants (Lycopersicon esculentum) for their use as potential plant growth-promoting rhizobacteria. Int J Curr Microbiol Appl Sci 2:406-417

Ahmed EA, Hassan EA, El Tobgy KMK, Ramadan EM (2014) Evaluation of rhizobacteria of some medicinal plants for plant growth-promotion and biological control. Ann Agric Sci 59:273-280

Alloway BJ (2009) Soil factors associated with zinc deficiency in crops and humans. Environ Geochem Health 31:537-548

Arcand JL (2001) Undernourishment and economic growth: the efficiency cost of hunger, Economic and social development paper no. 147. Food and Agriculture Organization, Rome

Barriuso J, Ramos Solano B, Santamaría C, Daza A, Gutierrez Manero FJ (2008) Effect of inoculation with putative plant growth-promoting rhizobacteria isolated from Pinus spp. on Pinus pinea growth, mycorrhization and rhizosphere microbial communities. J Appl Microbiol 105:1298-1309

Belimov AA, Safronova VI, Sergeyeva TA, Egorova TN, Matveyeva VA, Tsyganov VE, Borisov AY, Tikhonovich IA, Kluge C, Preisfeld A, Dietz KJ, Stepanok VV (2001) Characterization of plant 
growth-promoting rhizobacteria isolated from polluted soils and containing 1-aminocyclopropane-1carboxylate deaminase. Can J Microbiol 47:642-652

Bhattacharyya PN, Jha DK (2012) Plant growthpromoting rhizobacteria (PGPR): emergence in agriculture. World J Microbiol Biotechnol 28:1327-1350

Bloem J, de Ruiter P, Bouwman LA (1997) Soil food webs and nutrient cycling in agro-ecosystems. In: van Elsas JD, Trevors JT, Wellington HME (eds) Modern soil microbiology. Marcel Dekker, New York, pp 245-278

Cakmak I, Kalayci M, Ekiz H, Braun HJ, Kilinc Y, Yilmaz A (1999) Zinc deficiency as a practical problem in plant and human nutrition in Turkey: a NATOscience for stability project. Field Crop Res 60:175-188

Carvalho SMP, Vasconcelos MW (2013) Producing more with less: strategies and novel technologies for plantbased food biofortification. Food Res Int 54:961-971

de Souza R, Beneduzi A, Ambrosini A, da Costa PB, Meyer J, Vargas LK, Schoenfeld R, Passaglia LMP (2013) The effect of plant growth-promoting rhizobacteria on the growth of rice (Oryza sativa L.) cropped in southern Brazilian fields. Plant Soil 366:585-603

Dimkpa CO, Svatos A, Merten D, Büchel G, Kothe E (2008) Hydroxamate siderophores produced by Streptomyces acidiscabies E13 bind nickel and promote growth in cowpea (Vigna unguiculata L.) under nickel stress. Can J Microbiol 54:163-172

Dimkpa CO, Merten D, Svatoš A, Büchel G, Kothe E (2009) Siderophores mediate reduced and increased uptake of cadmium by Streptomyces tendae F4 and sunflower (Helianthus annuus), respectively. J Appl Microbiol 107:1687-1696

Donate-Correa J, León-Barrios M, Pérez-Galdona R (2005) Screening for plant growth-promoting rhizobacteria in Chamaecytisus proliferus (tagasaste), a forage tree-shrub legume endemic to the Canary Islands. Plant Soil 266:261-272

Egamberdieva D, Shrivastava S, Varma A (2015) Plantgrowth-promoting rhizobacteria (PGPR) and medicinal plants. Springer International Publishing, Cham

El-Tarabily KA (2008) Promotion of tomato (Lycopersicon esculentum Mill.) plant growth by rhizosphere competent 1-aminocyclopropane-1-carboxylic acid deaminase-producing streptomycete actinomycetes. Plant Soil 308:161-174

El-Tarabily KA, Sivasithamparam K (2006) Non-streptomycete actinomycetes as biocontrol agents of soil-borne fungal plant pathogens and as plant growth-promoters. Soil Biol Biochem 38:1505-1520

Erdal I, Yilmaz A, Taban S, Eker S, Torun B, Cakmak I (2002) Phytic acid and phosphorus concentrations in seeds of wheat cultivars grown with and without zinc fertilization. J Plant Nutr 25:113-127

Fan MS, Zhao FJ, Fairweather-Tait SJ, Poulton PR, Dunham SJ, McGrath SP (2008) Evidence of decreasing mineral density in wheat grain over the last 160 years. J Trace Elem Med Biol 22:315-324
FAO, WFP, IFAD (2012) The state of food insecurity in the world 2012. Economic growth is necessary but not sufficient to accelerate reduction of hunger and malnutrition. Food and Agriculture Organization, Rome

FAO, WFP, IFAD (2013) The state of food insecurity in the world 2013. The multiple dimensions of food security. Food and Agriculture Organization, Rome

FAO, WFP, IFAD (2014) The state of food insecurity in the world 2014. Strengthening the enabling environment for food security and nutrition. Food and Agriculture Organization, Rome

Garvin DF, Welch RM, Finley JW (2006) Historical shifts in the seed mineral micronutrient concentration of US hard red winter wheat germplasm. J Sci Food Agric $86: 2213-2220$

Giridhar Babu A, Shim J, Bang K, Shea PJ, Oh B (2014) Trichoderma virens PDR-28: a heavy metal-tolerant and plant growth-promoting fungus for remediation and bioenergy crop production on mine tailing soil. $\mathrm{J}$ Environ Manage 132:129-134

Glick BR (1995) The enhancement of plant growth by free-living bacteria. Can J Microbiol 41:109-117

Gopalakrishnan S, Vadlamudi S, Apparla S, Bandikinda P, Vijayabharathi R, Bhimineni RK, Rupela O (2013) Evaluation of Streptomyces spp. for their plant growth-promotion traits in rice. Can $\mathbf{J}$ Microbiol 59:534-539

Gopalakrishnan S, Vadlamudi S, Bandikinda P, Sathya A, Vijayabharathi R, Rupela O, Kudapa H, Katta K, Varshney RK (2014) Evaluation of Streptomyces strains isolated from herbal vermicompost for their plant growth-promotion traits in rice. Microbiol Res 169:40-48

Graham RD (2008) Micronutrient deficiencies in crops and their global significance. In: Alloway BJ (ed) Micronutrient deficiencies in global crop production. Springer, Heidelberg, pp 41-61

Graham RD, Welch RM, Saunders DA, Bouis HE, Bonierbale $M$, de Haan S, Burgos G, Thiele G, Liria R, Meisner CA, Beebe SE, Potts MJ, Kadian M, Hobbs PR, Gupta RJK, Twomlow S (2007) Nutritious subsistence food systems. Adv Agron 92:1-74

Graham RD, Knez M, Welch RM (2012) How much nutritional iron deficiency in humans globally is due to an underlying zinc deficiency? Adv Agron 115:1-40

Gupta AP (2005) Micronutrient status and fertilizer use scenario in India. J Trace Elem Med Biol 18:325-331

Haden RL (1938) Historical aspect of iron therapy in anemia. J Am Med Assoc 111:1059-1061

HarvestPlus (2013) Diving into delivery. 2013 Annual report. Last accessed at http://www.harvestplus.org/ sites/default/files/HarvestPlus\%202013\%20Annual\% 20Report.pdf on 31 Oct 2015

He LY, Zhang YF, Ma HY, Su LN, Chen ZJ, Wang QY, Qian M, Sheng XF (2010) Characterization of copper resistant bacteria and assessment of bacterial communities in rhizosphere soils of copper-tolerant plants. Appl Soil Ecol 44:49-55

Hoorman JJ, Islam R (2010) Understanding soil microbes and nutrient recycling. Fact Sheet SAG-16-10, The Ohio State University, USA 
Joshi PM, Juwarkar AA (2009) In vivo studies to elucidate the role of extracellular polymeric substances from Azotobacter in immobilization of heavy metals. Environ Sci Technol 43:5884-5889

Kalayci M, Torun B, Eker S, Aydin M, Ozturk M, Cakmak I (1999) Grain yield, zinc efficiency and zinc concentration of wheat cultivars grown in a zinc-deficient calcareous soil in field and greenhouse. Field Crop Res 63:87-98

Kataki PK (2002) Shifts in cropping system and its effect on human nutrition: case study from India. J Crop Prod 6:119-144

Kavamura VN, Santos SN, da Silva JL, Parma MM, Ávila LA, Visconti A, Zucchi TD, Taketani RG, Andreote FD, de Melo IS (2013) Screening of Brazilian cacti rhizobacteria for plant growth-promotion under drought. Microbiol Res 168:183-191

Kennedy G, Natel G, Shetty P (2003) The scourge of 'hidden hunger': global dimensions of micronutrient deficiencies. Food Nutr Agric 32:8-16

Khalid S, Asghar HN, Akhtar MJ, Aslam A, Zahir ZA (2015) Biofortification of iron in chickpea by plant growth-promoting rhizobacteria. Pak J Bot 47:1191-1194

Kuffner M, Puschenreiter M, Wieshammer G, Gorfer M, Sessitsch A (2008) Rhizosphere bacteria affect growth and metal uptake of heavy metal accumulating willows. Plant Soil 304:35-44

Kumar K, Singh N, Behlh HM, Srivastava S (2008) Influence of plant growth-promoting bacteria and its mutant on heavy metal toxicity in Brassica juncea grown in fly ash amended soil. Chemosphere 72:678-683

Liu W, Hou J, Wang Q, Ding L, Luo Y (2014) Isolation and characterization of plant growth-promoting rhizobacteria and their effects on phytoremediation of petroleum-contaminated saline-alkali soil. Chemosphere 117:303-308

Ma Y, Prasad MNV, Rajkumar M, Freitas H (2011) Plant growth-promoting rhizobacteria and endophytes accelerate phytoremediation of metalliferous soils. Biotechnol Adv 29:248-258

Majeed A, Abbasi MK, Hameed S, Imran A, Rahim N (2015) Isolation and characterization of plant growthpromoting rhizobacteria from wheat rhizosphere and their effect on plant growth-promotion. Front Microbiol 6:198

Medeot DB, Paulucci NS, Albornoz AI, Fumero MV, Bueno MA, Garcia MB, Woelke MR, Okon Y, Dardanelli MS (2010) Plant growth-promoting rhizobacteria improving the legume-rhizobia symbiosis. In: Khan MS, Musarrat J, Zaidi A (eds) Microbes for legume improvement. Springer, Vienna, pp 473-494

Mehta P, Walia A, Chauhan A, Shirkot CK (2013) Plant growth-promoting traits of phosphate-solubilizing rhizobacteria isolated from apple trees in trans Himalayan region of Himachal Pradesh. Arch Microbiol 195:357-369
Nascimento FX, Rossi MJ, Soares CRFS, McConkey BJ, Glick BR (2014) New insights into 1-aminocyclopropane-1-carboxylate (acc) deaminase phylogeny, evolution and ecological significance. PLoS One 9(6):e99168

Pellegrino E, Bedini S (2014) Enhancing ecosystem services in sustainable agriculture: biofertilization and biofortification of chickpea (Cicer arietinum L.) by arbuscular mycorrhizal fungi. Soil Biol Biochem 68:429-439

Pimentel D, Pimentel M (2003) Sustainability of meatbased and plant-based diets and the environment. Am J Clin Nutr 78:660S-663S

Pingali PL, Roger PA (2012) Impact of pesticides on farmer health and the rice environment. Springer, Dordrecht

Prasad SA (1991) Discovery of human zinc deficiency and studies in an experimental human model. Am J Clin Nutr 53:403-412

Prasad SA (2003) Zinc deficiency. Br Med J 326:409-410

Prasad SA, Schulert AR, Miale A, Farid Z, Sandstead HH (1963) Zinc and iron deficiencies in male subjects with dwarfism and hypogonadism but without ancylostomiasis, schistosomiasis or severe anemia. Am J Clin Nutr 12:437-444

Prasanna R, Bidyarani N, Babu S, Hossain F, Shivay YS, Nain L (2015) Cyanobacterial inoculation elicits plant defense response and enhanced $\mathrm{Zn}$ mobilization in maize hybrids. Cogent Food Agric 1:998507

Rajkumar M, Freitas H (2008) Effects of inoculation of plant growth-promoting bacteria on $\mathrm{Ni}$ uptake by Indian mustard. Bioresour Technol 99:3491-3498

Rajkumar M, Ma Y, Freitas H (2008) Characterization of metal-resistant plant growth-promoting Bacillus weihenstephanensis isolated from serpentine soil in Portugal. J Basic Microbiol 48:1-9

Rajkumar M, Sandhya S, Prasad MNV, Freitas H (2012) Perspectives of plant-associated microbes in heavy metal phytoremediation. Biotechnol Adv 30:1562-1574

Rana A, Joshi M, Prasanna R, Shivay YS, Nain L (2012a) Biofortification of wheat through inoculation of plant growth-promoting rhizobacteria and cyanobacteria. Eur J Soil Biol 50:118-126

Rana A, Saharan B, Nain L, Prasanna R, Shivay YS (2012b) Enhancing micronutrient uptake and yield of wheat through bacterial PGPR consortia. Soil Sci Plant Nutr 58:573-582

Rana A, Kabi SR, Verma S, Adak A, Pal M, Shivay YS, Nain L (2015) Prospecting plant growth-promoting bacteria and cyanobacteria as options for enrichment of macro-and micronutrients in grains in rice-wheat cropping sequence. Cogent Food Agric 1(1):1037379

Ren Q, Fan F, Zhang Z, Zheng X, DeLong GR (2008) An environmental approach to correcting iodine deficiency: supplementing iodine in soil by iodination of irrigation water in remote areas. $\mathrm{J}$ Trace Elem Med Biol 22:1-8 
Rudresh DL, Shivaprakash MK, Prasad RD (2005) Effect of combined application of Rhizobium, phosphate solubilizing bacterium and Trichoderma spp. on growth, nutrient uptake and yield of chickpea (Cicer aritenium L.). Appl Soil Ecol 28:139-146

Schütze E, Klose M, Merten D, Nietzsche S, Senftleben D, Roth M, Kothe E (2014) Growth of streptomycetes in soil and their impact on bioremediation. J Hazard Mater 267:128-135

Sessitsch A, Kuffner M, Kidd P, Vangronsveld J, Wenzel WW, Fallmann K, Puschenreiter M (2013) The role of plant-associated bacteria in the mobilization and phytoextraction of trace elements in contaminated soils. Soil Biol Biochem 60:182-194

Shahzad Z, Rouached H, Rakha A (2014) Combating mineral malnutrition through iron and zinc biofortification of cereals. Compr Rev Food Sci Food Saf 13:329-346

Sharma A, Shankhdhar D, Shankhdhar SC (2013) Enhancing grain iron content of rice by the application of plant growth-promoting rhizobacteria. Plant Soil Environ 59:89-94

Silini-Chérif H, Silini A, Ghoul M, Yadav S (2012) Isolation and characterization of plant growth-promoting traits of a rhizobacteria: Pantoea agglomerans $1 \mathrm{ma} 2$. Pak J Biol Sci 15:267-276

Singh MV (2009) Micronutrient nutritional problems in soils of India and improvement for human and animal health. Indian J Fertil 5:11-16

Singh SK, Pancholy A, Jindal SK, Pathak R (2011) Effect of plant growth-promoting rhizobia on seed germination and seedling traits in Acacia senegal. Ann For Res 54:161-169

Sirohi G, Upadhyay A, Srivastava PS, Srivastava S (2015) PGPR mediated zinc biofertilization of soil and its impact on growth and productivity of wheat. J Soil Sci Plant Nutr 15:202-216

Stein AJ (2009) Global impacts of human mineral malnutrition. In: Brar MS, Mukhopadhyay SS (eds) Proceedings of the IPI-OUAT-IPNI international symposium 2009. IPI, Horgen, Switzerland and IPNI, Norcross, USA, pp 45-82

Thokchom E, Kalita MC, Talukdar NC (2014) Isolation, screening, characterization and selection of superior rhizobacterial strains as bioinoculants for seedling emergence and growth-promotion of Mandarin orange (Citrus reticulata Blanco). Can J Microbiol 60:85-92

Trivedi P, Pandey A (2008) Plant growth-promotion abilities and formulation of Bacillus megaterium strain B 388 (MTCC6521) isolated from a temperate Himalayan location. Indian J Microbiol 48:342-347

Trivedi P, Pandey A, Sa T (2007) Chromate reducing and plant growth-promoting activities of psychrotrophic Rhodococcus erythropolis MtCC 7905. J Basic Microbiol 47:513-517

Uren NC (2007) Types, amounts and possible functions of compounds released into the rhizosphere by soil- grown plants. In: Pinton R, Varanini Z, Nannipieri P (eds) The rhizosphere: biochemistry and organic substances at the soil-plant interface. CRC Press, Boca Raton, pp 1-22

Verma JP, Yadav J, Tiwari KN, Kumar A (2013) Effect of indigenous Mesorhizobium spp. and plant growthpromoting rhizobacteria on yields and nutrients uptake of chickpea (Cicer arietinum L.) under sustainable agriculture. Ecol Eng 51:282-286

von Grebmer K, Saltzman A, Birol E, Wiesmann D, Prasai N, Yin S, Yohannes Y, Menon P, Thompson J, Sonntag A (2014) 2014 Global Hunger Index: the challenge of hidden hunger. Welthungerhilfe, International Food Policy Research Institute, and Concern Worldwide, Bonn/Washington, DC/Dublin

Wahyudi AT, Astuti RP, Widyawati A, Meryandini A, Nawangsih AA (2011) Characterization of Bacillus sp. strains isolated from rhizosphere of soybean plants for their use as potential plant growth for promoting rhizobacteria. J Microbiol Antimicrob 3:34-40

Wani PA, Khan MS, Zaidi A (2008) Effect of metaltolerant plant growth-promoting Rhizobium on the performance of pea grown in metal-amended soil. Arch Environ Contam Toxicol 55:33-42

Welch RM (2001) Micronutrients, agriculture and nutrition; linkages for improved health and wellbeing. In: Singh K, Mori S, Welch RM (eds) Perspectives on the micronutrient nutrition of crops. Scientific Publishers, Jodhpur, pp 247-289

Welch RM (2002a) The impact of mineral nutrients in food crops on global human health. Plant Soil 247:83-90

Welch RM (2002b) Breeding strategies for biofortified staple plant foods to reduce micronutrient malnutrition globally. J Nutr 132:S495-S499

White PJ, Broadley MR (2009) Biofortification of crops with seven mineral elements often lacking in human diets - iron, zinc, copper, calcium, magnesium, selenium and iodine. New Phytol 182:49-84

WHO (2002) The world health report 2002. World Health Organization, Geneva. Last accessed at http://www. who.int/whr/2002/ on 31 Oct 2015

WHO (2004) Vitamin and mineral requirements in human nutrition. World Health Organization, Geneva. Last accessed at http://www.who.int/iris/bitstream/10665/ 42716/http://apps.who.int//iris/bitstream/10665/42716/ 1/9241546123.pdf on 31 Oct 2015

Wu SC, Cheung KC, Luo YM, Wong MH (2009) Effects of inoculation of plant growth-promoting rhizobacteria on metal uptake by Brassica juncea. Environ Pollut 140:124-135

Zahid M, Abbasi K, Hameed S, Rahim N (2015) Isolation and identification of indigenous plant growthpromoting rhizobacteria from Himalayan region of Kashmir and their effect on improving growth and nutrient contents of maize (Zea mays L.). Front Microbiol 6:207 